\title{
Alcohol Oxidase Is a Novel Pathogenicity Factor for Cladosporium fulvum, but Aldehyde Dehydrogenase Is Dispensable
}

\author{
G. Segers, ${ }^{1,2}$ N. Bradshaw, ${ }^{3}$ D. Archer, ${ }^{4}$ K. Blissett, ${ }^{1}$ and R. P. Oliver ${ }^{1}$ \\ ${ }^{1}$ Department of Physiology, Carlsberg Laboratory, Gamle Carlsberg Vej 10, DK-2500 Copenhagen Valby, \\ Denmark; ${ }^{2}$ Center for Agricultural. Biotechnology, 5115 Plant Sciences Building, University of Maryland, \\ College Park 20742, U.S.A.; ${ }^{3}$ University of East Anglia, School of Biological Sciences, Norwich NR4 7TJ, \\ U.K.; ${ }^{4}$ Institute of Food Research, Norwich Research Park, Colney, Norwich NR4 7UA, U.K. \\ Accepted 7 November 2000.
}

Cladosporium fulvum is a mitosporic ascomycete pathogen of tomato. A study of fungal genes expressed during carbon starvation in vitro identified several genes that were up regulated during growth in planta. These included genes predicted to encode acetaldehyde dehydrogenase (Aldh1) and alcohol oxidase (Aox1). An Aldh1 deletion mutant was constructed. This mutant lacked all detectable ALDH activity, had lost the ability to grow with ethanol as a carbon source, but was unaffected in pathogenicity. Aox 1 expression was induced by carbon starvation and during the later stages of infection. The alcohol oxidase enzyme activity has broadly similar properties $\left(K_{m}\right.$ values, substrate specificity, $\mathrm{pH}$, and heat stability) to yeast enzymes. Antibodies raised to Hansenula polymorpha alcohol oxidase (AOX) detected antigens in Western blots of starved C. fulvum mycelium and infected plant material. Antigen reacting with the antibodies was localized to organelles resembling peroxisomes in starved mycelium and infected plants. Disruption mutants of Aoxl lacked detectable AOX activity and had markedly reduced pathogenicity as assayed by two different measures of fungal growth. These results identify alcohol oxidase as a novel pathogenicity factor and are discussed in relation to peroxisomal metabolism of fungal pathogens during growth in planta.

Cladosporium fulvum is the cause of the disease tomato leaf mould (Oliver et al. 2000). It infects its host by penetrating the stomata and ramifying through the intercellular spaces. Sporulation occurs approximately 12 days after infection under optimal conditions. No specific infection structures are elaborated and no obvious damage is caused to the plant. It therefore has been speculated that $C$. fulvum represents a rudimentary or primitive type of biotrophic pathogen.

Details of the mechanisms of pathogenicity are still obscure. Mutants ablated in two genes, ECP1 and ECP2, were reduced in pathogenicity but the function of these genes is

Corresponding author: R.P. Oliver; Current address: Australian Centre for Necrotrophic Fungal Pathogens, Murdoch University, WA 6150, Australia; Telephone: +61 89360 7404; Fax: +61 89360 6303; E-mail: roliver@central.murdoch.edu.au unknown (De Wit and Joosten 1999). Because many genes important for pathogenicity are induced by in vitro starvation conditions, a screen was made of genes induced during starvation (Coleman et al. 1997). Two of these genes were identified as alcohol dehydrogenase (Adhl) and acetaldehyde dehydrogenase (Aldhl) and both were found to be plant induced. This screen was extended (Oliver et al. 2000; Segers 1998), uncovering a total of 61 starvation-induced genes, one of which was predicted to encode alcohol oxidase (Aoxl).

A limited number of Candida, Hansenula, Pichia, and Torulopsis yeast species are capable of utilizing methanol as the sole carbon and energy source (Hazeu et al. 1972). Alcohol oxidase (AOX) plays a key role in methanol metabolism in Candida boidinii because a mutant that lacked this enzyme was incapable of growth on methanol (Sahm and Wagner 1973). AOX activity has been described for several basidiomycetes (Bringer et al. 1979; Janssen et al. 1965; Kerwin and Ruelius 1969; Nishida and Eriksson 1987) but has not been identified in filamentous ascomycetes.

The enzyme catalyses the irreversible oxidation of methanol (or ethanol) to formaldehyde (or acetaldehyde) and hydrogen peroxide with the use of oxygen as electron acceptor. The hydrogen peroxide is probably decomposed by catalase, which is specifically induced during growth of yeasts on methanol (Kato et al. 1974). Cytochemical studies of methanol-utilizing yeasts revealed that AOX and catalase are located in peroxisomes (Van Dijken et al. 1975; Veenhuis et al. 1976). During growth on methanol, AOX comprises $20 \%$ of the soluble protein (Van Dijken et al. 1976b) and over $80 \%$ of the total cell volume is occupied by peroxisomes.

Ethanol oxidation by AOX produces acetaldehyde, which is oxidized to acetate with the enzyme acetaldehyde dehydrogenase. The characterization of these genes and enzymes is described, and the effect of gene disruption on pathogenicity is detailed.

\section{RESULTS}

Isolation and sequence analysis of Aox1 and Aldh1.

The cDNA clone PSI-47, which was isolated in a differential screen of a cDNA library for genes induced by starvation (Coleman et al. 1997), showed a very high level of similarity 
to AOX from methylotrophic yeasts. The cognate gene is designated Aoxl.

The cDNA and corresponding genomic sequence of Aoxl identified a coding region of 2,345 nucleotides containing five introns (GenBank accession no. AF275346). Analysis of the promoter reveals two putative CAAT boxes at positions -210 and -609 and a TATA box at position -130 relative to the ATG codon. CAAT and TATA boxes are motifs commonly found in promoters of fungi and higher eukaryotes (Gurr et al. 1987). The introns are bound by GT and AG base pairs at their $5^{\prime}$ and $3^{\prime}$ ends, respectively, and range in size from 49 to 121 bases. Introns 3 and 4 are situated very close together, and the exon between them is only 13 bases long. A putative polyadenylation site is at position 2,469, 121 bases downstream of the stop codon.

The predicted protein contains 665 amino acids and has a molecular weight of approximately $74 \mathrm{kDa}$. Figure 1 shows an alignment of the $C$. fulvum protein with AOX from Pichia pastoris, Hansenula polymorpha, and C. boidinii. C. fulvum AOX shows the highest level of similarity to the $P$. pastoris AOX1, with which it shares $65.6 \%$ identity. The protein sequence was analyzed by the PredictProtein server (Rost et al. 1994). A GMC oxidoreductase-2 pattern, [GS]-[PSTA]-X(2)[ST]-P-X-[LIVM](2)-X(2)-S-G-[LIVM]-G, is present as $\mathrm{G}_{284}$ TLSSPLILQRSGIG $_{298}$ (Cavener 1992) and can be found in AOX from the other organisms. This pattern is conserved in glucose-, methanol- and cholesterol oxidoreductases. Residues 13 to 18 reveal a putative flavin adenine dinucleotide (FAD) binding site $\mathrm{G}-\mathrm{X}-\mathrm{G}-\mathrm{X}(2) \mathrm{G}$ within the predicted ADP-binding $\beta-\alpha-\beta$ motif (Wierenga et al. 1986). Residues A-R-L at the C terminus of the sequence are a potential PTS1 peroxisomal targeting signal whose consensus sequence has been determined as [STAGCN]-[RKH]-[LIVMAFY] (De Hoop and Ab 1992; Gould et al. 1989).

A Southern blot of $C$. fulvum genomic DNA digested separately with five different restriction enzymes was hybridized with a 600-bp EcoRV-XhoI fragment corresponding to nucleotides 25 to 631 . The fragment hybridized to a single band in all of the lanes (data not shown), consistent with Aoxl being single copy.

The cDNA clone PSI-9 (Coleman et al. 1997) was completely sequenced (GenBank accession no. AF275347) and encodes a putative full-length protein of 497 amino acids. Alignment of the full sequence confirmed an earlier finding that the most similar sequences are acetaldehyde dehydrogenases from Cladosporium herbarium, Alternaria alternata, and Aspergillus nidulans. Amino acid identities are 84, 78, and $73 \%$ respectively. The corresponding C. fulvum gene is referred to as Aldhl.

\section{Expression of the Aox1 gene in vitro and in planta.}

The expression of Aoxl under different nutritional conditions was investigated by Northern blot analysis with either of the two fragments of insert DNA, totaling $1.4 \mathrm{~kb}$, that were released either by Kpn 1 and Sma 1 from PSI-47 or the $C$. fulvum actin gene (Coleman et al. 1997) as probes. Expression was quantified relative to the actin signal. The strongest expression was found in mycelium grown in medium containing nitrogen but no carbon. Mycelium starved for carbon and nitrogen accumulated Aoxl to a lesser extent. The addition of carbon, with or without nitrogen, resulted in very weak signals (Fig. 2A).
Northern blots were prepared from RNA isolated from uninfected tomato plants and from infected plants at different stages of infection and then hybridized as described above. In infected plants, Aoxl mRNA could be detected at all time points tested, although it was very low at 7 days postinfection (dpi). Expression of Aoxl showed a strong increase between 10 and 12 dpi (Fig. 2B). This experiment was repeated with similar results.

\section{Analysis of AOX enzyme activity.}

Crude protein extract from carbon-starved and nonstarved mycelia was assayed for AOX activity. Only starved mycelia exhibited AOX activity. The $K_{m}$ values for methanol, ethanol, and 1-propanol were determined. The activity was greatest for small primary alcohols, with methanol and ethanol being almost equally good substrates, and was considerably lower with longer (1-propanol and butanol) and secondary alcohols (isopropanol and 2-butanol) (Table 1). The activity exhibited a broad $\mathrm{pH}$ optimum and was highest in potassium phosphate buffer at $\mathrm{pH} 8.0$ (data not shown). The activity decreased quickly during incubation at higher temperatures. After a 15min incubation at $30^{\circ} \mathrm{C}, 50 \%$ of the activity was left and the enzyme was completely inactivated after incubation at $45^{\circ} \mathrm{C}$. AOX activity also was detected in infected plants at $14 \mathrm{dpi}$, with a similar substrate specificity consistent with this being the same enzyme activity as in carbon-starved mycelium (results not shown).

\section{Use of heterologous antibodies to detect AOX.}

The strong homology between Aoxl from C. fulvum and methylotrophic yeasts suggested similar serological properties. Polyclonal antibodies against AOX from $H$. polymorpha were used to detect the $C$. fulvum protein on Western blots. The Western blots showed one major band in the lanes with protein from carbon-starved mycelium and from infected plants but none in lanes with mycelium from full media or uninfected plants (Fig. 3).

The subcellular localization of AOX in C. fulvum was determined with affinity-purified anti-AOX and gold-labeled secondary antibodies on ultrathin sections of mycelium and infected plant material. In sections from carbon-starved mycelium, the gold particles were located mainly in organelles, which are probably peroxisomes (Fig. 4A). No specific labeling was observed in sections from mycelium that had been grown in full medium or when anti-AOX antibodies were omitted. Labeling of fungal organelles was observed in sections of infected plant material (Fig. 4B to D). The labeled

Table 1. Activity and $K_{m}$ values of alcohol oxidase (AOX) toward different substrates

\begin{tabular}{lcc}
\hline Substrate & Activity $^{\mathbf{a}}$ & $\boldsymbol{K}_{\boldsymbol{m}}$ value $(\mathbf{m M})$ \\
\hline Methanol & 30.8 & 19.4 \\
Ethanol & 25.8 & 22.4 \\
1-Propanol & 18.8 & 72.6 \\
Isopropanol & 2.8 & \\
1-Butanol & 5.5 & \\
2-Butanol & 0.29 & \\
Glycerol & 0.0 & \\
\hline
\end{tabular}

${ }^{a}$ Numbers are $\mu \mathrm{M}$ substrate per min per mg of protein. Activity was determined by measuring AOX in crude protein extracts from carbonstarved mycelium with $100 \mathrm{mM}$ substrate. 
organelles were similar to those observed in carbon-starved mycelium. For the first time point ( $2 \mathrm{dpi})$, tomato leaves were inoculated with $10^{8}$ of conidia per ml, rather than the usual $10^{5}$ of conidia per $\mathrm{ml}$, in order to attain more fungal biomass. Labeling was visible in small, peroxisome-like organelles in hyphal cells, growing on the outside of the leaf. The diameter of the hyphae was approximately $1 \mu \mathrm{m}$ (Fig. 4C). At 8 dpi, the amount of fungal biomass is still relatively low (KarpovichTate et al. 1998) and, although several different sections were labeled and viewed, no labeling of fungal cell organelles could

$\begin{array}{llll}\text { CLAFUL } & 1 & \text { MTIPDEVDII VCGGGSCGCV VAGRLANLD. HKLOVMLIEA GESNLNNPWV FRPGIYPRNM } \\ \text { PICPAS } & 1 \text { MAIPEEFDIL VLGGGSSGSC IAGRLANLD. HSLKVGLIEA GENNLNNPWV YLPGIYPBNM } \\ \text { CANBOI } & 1 \text { MAIPEEFDVI VCGGGSTGCV IAGRLANVD. ENLKVLLIEN GENNLNNPWV YLPGIYPRNM } \\ \text { HANPOL } & 1 \text { MAIPDEFDII VVGGGSTGCC IAGRLANLDD ONLTVALIEG GENNINNPWV YLPGVYPRNM }\end{array}$

CLAFUL 60 KLDSKTATFY YSRPSEWLSG RRAIVPCANI LGGASSINFM MYTRASASDY DDFQAKGWTT PICPAS 60 KLDSKTASFY TSNPSPHLNG RRATVPCANI LGGGSSINFM MYTRGSASDY DDFEAEGWKT CANBOI 60 RLDSKTATFY NSRPSKHLNG RRAIVPQANI LGGGSSINFM MYTRASASDY DDWESEGWTT HANPOL 61 RLDSKTATFY SSRPSKALNG RRAIVPCANI LGGGSSINFL MYTRASASDY DDWESEGWST

CLAFUL 130 KELLPLMKKH ETYORACQNR VLHGFDGPIK VSFGNYTYPV MQDFLRAAES OGIPISDDLE PICPAS 130 KDLLPLMKKT ETYORACNNP EIHGFEGPIK VSFGNYTYPV CODFLRATES QGIPYVDDLE CANBOI 130 DELLPLMKKF ETYQRPCNNR DVHGFDGPIK VSFGNYTYPQ CQDFLAACET QGIPYVDDLE HANPOL 131 DELLPLIKKI ETYORPCNNR DLHGFDGPIK VSFGNYTYPT CQDFLRAAES QGIPVVDDLE

CLAFUL 180 DLNTGHGAQH WLKWINRDTG RRSDSAHAYI HSTRQHFENL HLVCNTKVDK VILEGNKAVG PICPAS 180 DLVTAHGAEH WLKWINRDTG RRSDSAHAFV HSTMRNHDNL YLICNTKVDK IIVEDGRAAA CANBOI 180 DLKTSHGAEQ WLKWINRDFG RRSDTAHAFI HSTMRNKENL FLMTNTKVDK VIIEDGRAVA HANPOL 181 DFKTSHGAEH WLKWINRDLG RRSDSAHAYV HPTMRNKQSL FLITSTKCDK VIIEDGKAVA

CLAFUL 240 VKTIPTKPLH PNENKSRIFK ARKOIIVSGG TLSSPLILQR SGIGDSQKLR KAGVKPIIDL PICPAS 240 VRTVPSKPLN AKKPTHKVYR ARTQIVLSCG TISSPLVLQR SGFGDPIKLR AAGVKPLVNL CANBOI 240 VRTVPSKPIG DSK.VSBTFK ARKOTVVSCG TVSSPMVLOR SGIGEPSKLA AAGVKPIVEL HANPOL 241 VRTVPMKPLN PKKPVSRTFR ARKOIVISCG TISSPLVLOR SGIGAAHHLR SVGVKPIVDL

CLAFUL 300 PGVGLNFQDH YLYFSLYRAK PWAESFDEFV RGNKEVQDKV FGQWELNGTG PLATNAIEAG PICPAS 300 PGVGRNFQDH YCFFSPYRIK PQYESFDDFV RGDANIQKKV FDQWYANGTG PLATNGIEAG CANBOI 299 PGVGRNFQDH FCYFVPYRIK QDSESFDAFV SGDKEAQKSA FDQWYATGAG PLATNGIEAG HANPOL 301 PGVGENFQDH YCFFTPYYVK PDVPTFDDFV RGDPVAQKAA FDQWYSNKDG PLTTNGIEAG

CLAFUL 360 VKARPTEQEL EDMKSWPFPE FLSGWDSYFK NKPDKPVMHW AVVAGWFGDH MHVPPGKFFS PICPAS 360 VKIRPTPEEL SQMD. .. . ES FOEGYREYFE DKPDKPVMHY SIIAGFFGDH TKIPPGKYMT CANBOI 359 VKIRPTEAEL ATAD.....KA FQQGWESYFE NKPDKPLMHY SVISGFFGDH TRLPPGKYMT HANPOL 361 VKIRPTEEEL ATAD. . . ED FRRGYAEYFE NKPDKPLMHY SVISGFFGDH TKIPNGKFMT

CLAFUL 419 MFHFLEYPFS RGFTHITSPN PYEAPDFDAG FMNDRRDMAP MVWGYIKSRE TARRMDAYAG PICPAS 416 MFHFLEYPFS RGSIHITSPD PYATPDFDPG FMNDERDMAP MVWSYKKSRE TARKMDHFAG CANBOI 415 MFHFLEYPFS RGWLHISSDD PYAAPDFDPG FMNDDRDMWP MVWAFKKSRE TARRMECFAG HANPOL 417 MFHFLEYPFS RGFVRITSAN PYDAPDFDPG FLNDERDLWP MWWAKKSRE TARRMESFAG

CLAFUL 479 EVINMHPFYA YDSPARCKDL DLETTNAYAG PDHITANIQV GSWTVPKEAG KAPEPSFMNN PICPAS 476 EVTSHHPLFP YSSEARAYEM DLETSNAYGG PLNL TAGLAH GSWTOPLKKP AGRNEGHVTS CANBOI 475 EPTAFHPHYK VDSPARALEQ SAEDTKKVAG PLHLTANLYH GSWSTPIGEA DKHDPNHVTS HANPOL 477 EVTSHHPLFK VDSPARARDL DLETCSAYAG PKHLTANLYH GSWTVPIDKP TPKNDFHVTS

CLAFUL 539 HQQHIQE. DL QYSKDDLLAV EEWVKRHVET TWHSLGTCSM APKNGNSIVK HG. VLDERLN PICPAS 536 NQVELHP.DI EYDEEDDKAI ENYIREHTET TWHCLGTCSI GPREGSKIVK WGGVLDHRSN CANBOI 535 SHINVYSKDI QYTKEDDEAI ENYIKEHAET TWHCLGTNSM APREGNKNAP EGGVLDPRLN HANPOL 537 NQVQLHS.DI EYTEEDDEAI VNYIKEHTET TWHCLGTCSM APREGSKIAP KGGVLDARLN

CLAFUL 597 VHGVKNLKVA DLSICPDNVG CNTYSTALLI GEKCAVLTAE DLGYTGRALD MRVPDYQAN. PICPAS 595 VYGVKGLKVG DLSVCPDNVG CNTYTTALLI GEKTATLVGE DLGYTGEALD MTVPQFKLGT CANBOI 595 VHGVKGLKVA DLSVCPDNVG CNTFSTALTI GEKAAVLVAE DLGYSGSELD MEVPQHKLKT HANPOL 596 VYGVQNLKVA DLSVCPDNVG CNTYSTALTI GEKAATLVAE DLGYSGSDLD MTIPNFRLGT

CLAFUL 656 REITGLARL

PICPAS 655 YEKTGLARF

CANBOI 655 YEOTGAARY

HANPOL 656 YEETGLARF

Fig. 1. Alignment of alcohol oxidase from Cladosporium fulvum (CLAFUL; GenBank accession no. AF375246) with Pichia pastoris (PICPAS; EMBL database no. XO2646), Candida boidinii (CANBOI; EMBL database no. M81702), and Hansenula polymorpha (HANPOL; EMBL database no. A11156). Identical amino acid residues are shaded. GMC-oxidoreductase pattern is indicated by solid lines. C-terminal peroxisomal targeting signal is in bold. 
be seen (data not shown). At 14 dpi, the fungus was growing abundantly within the plant leaf and labeled organelles could be observed (Fig. 4B and D). The microbodies varied in size from 0.4 to $1.1 \mu \mathrm{m}$ in diameter. The diameter of the hyphae is 3.5 to $4.5 \mu \mathrm{m}$. An extracellular matrix was commonly observed between fungal hyphae and plant cells. In the plant cells, microbodies containing crystals were sometimes observed (Fig. 4D).

\section{Targeted disruption of Aox1 and Aldh1.}

A gene-replacement vector was constructed in which the upstream and downstream regions of the Aoxl gene were ligated on either side of the hygromycin (HYG) cassette encoding hygromycin resistance. The resulting vector (p130-1) contained $5.5 \mathrm{~kb}$ of $C$. fulvum DNA sequences to promote the replacement of Aoxl with the HYG cassette (Fig. 5). Transformation of $C$. fulvum was carried out with $7.5 \mu \mathrm{g}$ of linearized p130-1 or $5 \mu \mathrm{g}$ of pBluescript SK (pBS)::HYG as a control. Single spore isolates of 105 transformants were screened for the replacement of Aoxl by the HYG cassette with colony-lift hybridization. Nylon filters were probed with a labeled 600-bp EcoRV-XhoI fragment of the Aoxl gene (Fig. 5, probe 1). Fourteen transformants that did not hybridize were selected for further analysis. The mutants were grown in liquid B5 for 4 days and then transferred to B5 lacking carbon for $16 \mathrm{~h}$ to induce Aoxl expression. One mutant retained activity. The other mutants $(\Delta 12, \Delta 103$, and 11 others not shown) had no detectable AOX activity.
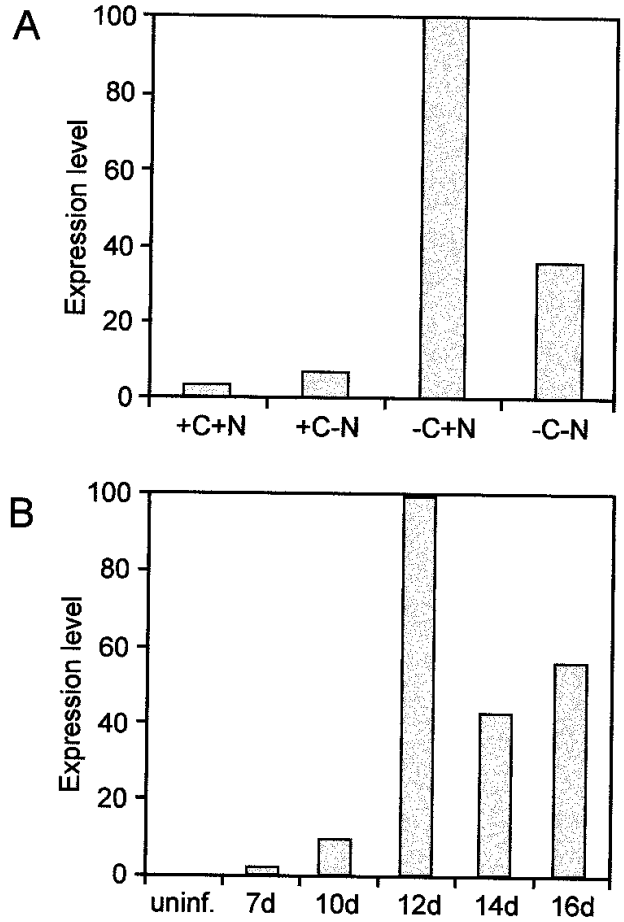

Fig. 2. Aoxl gene expression levels measured by quantitation of Northern blots: A, Expression of Aoxl gene in Cladosporium fulvum grown in vitro in complete media $(+\mathrm{C}+\mathrm{N})$, in media lacking nitrogen $(+\mathrm{C}-\mathrm{N})$ or carbon $(-\mathrm{C}+\mathrm{N})$, or in media lacking carbon and nitrogen $(-\mathrm{C}-\mathrm{N})$. B, Expression of Aox1 gene during growth of C. fulvum in planta. RNA from uninfected plants and from plants harvested 7, 10, 12, 14, and 16 days postinoculation. Histogram bars indicate the Aoxl gene signal divided by the signal given when actin cDNA was used as the probe.
Genomic DNA was prepared, blotted, and probed with Aoxl and HYG sequences. DNA was digested with KpnI because a site for this enzyme in the Aoxl gene was absent in p130-1. A labeled 600-bp polymerase chain reaction (PCR) fragment (Fig. 5; probe 2) derived from the promotor region of Aoxl hybridized to a 9-kb KpnI fragment in genomic DNA from wild-type $C$. fulvum (marked a) (Fig. 6). In the event of a gene replacement, the fragment should be at least $14.7 \mathrm{~kb}$ (marked b) because neither the HYG cassette $(2.7 \mathrm{~kb})$ nor the Aoxl-downstream fragment in p130-1 (3 kb) contain a KpnI site. Figure 6A shows that in both mutants lacking AOX activity, the probe hybridized to a DNA fragment larger than it did in the wild type, which is consistent with a genereplacement event. Additionally, no ectopic integrations of p130-1 could be detected. DNA of transformants obtained with pBS::HYG (Hyg5 and Hyg8) hybridized to a band of a similar size as wild-type C. fulvum (Fig. 6A). A similar Southern blot containing KpnI-digested genomic DNAs was hybridized with a labeled 700-bp BamHI-HindIII fragment from pBS::HYG (Figs. 5 [probe 3] and 6B). The probe hybridized to a genomic DNA fragment of $\Delta 12$ and $\Delta 103$ of similar size as the band detected by probe 2 (marked c) (Fig. 6A). Probe 3 hybridized to different bands compared with probe 2 in transformants Hyg5 and Hyg8, which is consistent with the integration of the vector at different places of the genome. As expected, there was no hybridization to wild type.

A similar protocol was used to generate knockout mutants of Aldhl. A genomic clone was isolated containing the entire coding region plus $3.9 \mathrm{~kb}$ of upstream- and $1.9 \mathrm{~kb}$ of downstream-flanking DNA. Plasmid pNOM 929 was constructed by inserting $2.1 \mathrm{~kb}$ of downstream and $1.8 \mathrm{~kb}$ of upstream sequence into pBS::HYG (Fig. 7). After transformation, PCR with primers (Aldh1 and Aldh2; see below) binding to Aldh1 sequences on either side of the HYG cassette was used to

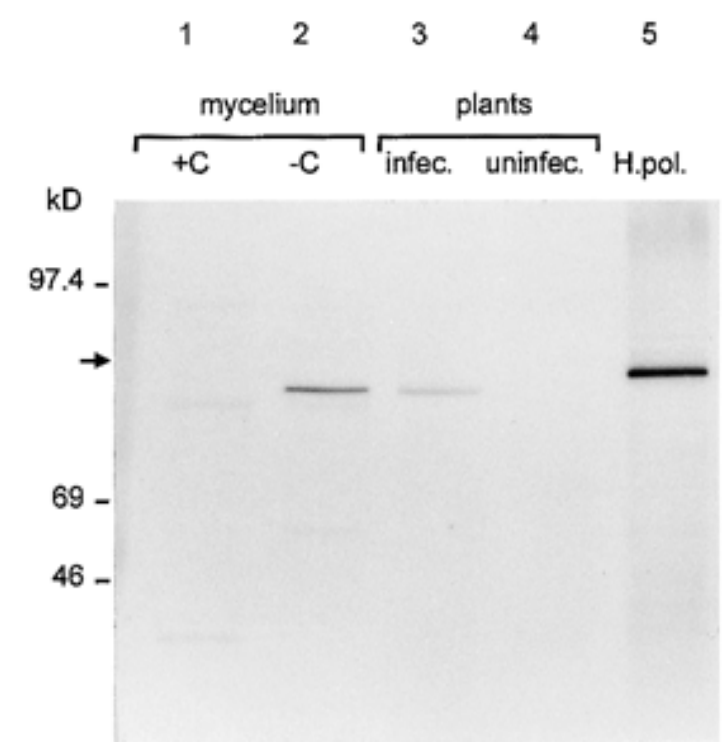

Fig. 3. Western blot showing cross reaction of the anti-alcohol oxidase (AOX) antibodies of Hansenula polymorpha with AOX from Cladosporium fulvum. The lanes contain $7.5 \mu \mathrm{g}$ of protein from mycelium grown in vitro with (lane 1) and without carbon (lane 2), with infected (lane 3 ) and uninfected plants (lane 4), and with $2 \mu \mathrm{g}$ of protein from $H$. polymorpha induced on methanol (lane 5). Arrow indicates the size of AOX from $H$. polymorpha. 
screen 73 transformants for gene-replacement events. One transformant (K29.56) had the expected band pattern. K29.55 had the PCR pattern that is expected following ectopic insertion and was included as a control. These interpretations were confirmed by Southern blotting (Fig. 8). Genomic DNA was cut with BamHI, $X b a \mathrm{I}, P s t \mathrm{I}$, and EcoRI singly and in pairs. These enzymes did not cut the Aldhl coding region but did cut the HYG cassette. The probe and the Aldhl coding region hybridized to one major band in the lanes with wild-type R4 DNA, although fainter, larger bands were indicative of partial digestion. Each of these bands also was present in the ectopic transformant 55, which showed additional bands that were indicative of the insertion of one copy of pNOM929 at an ectopic location. The lanes with DNA from the replacement transformant K29.56 exhibit bands of $3 \mathrm{~kb}$ when digested with BamH1, 0.7 and $2.9 \mathrm{~kb}$ with Bam $\mathrm{H} 1$ and $X b a \mathrm{I}, 6.3$ and $1 \mathrm{~kb}$ with PstI, with or without EcoRI. Each of these bands was predicted from digests of the genomic clone from which pNOM929 was derived.

Further confirmation of gene replacement was obtained by a Northern blot probed with PSI-9 (Fig. 9) and enzyme assays. RNA was prepared from mycelium grown with and without carbon as starvation to induce expression of Aldhl (Coleman et al. 1997). The probe hybridized to a band of $1.5 \mathrm{~kb}$ in $\mathrm{R} 4$ and K29.55, the ectopic insertion mutant. This band was absent in K29.56, the replacement mutant. K29.56 and K29.55 produced an aberrant band of $0.9 \mathrm{~kb}$, which probably corresponds to a transcript from pNOM 929. K29.56 also lacked detectable ALDH activity and the ability to grow on ethanol as sole carbon source (data not shown).

\section{Pathogenicity of transformants.}

Pathogenicity assays were carried out with the wild-type strain R4, the Aldhl knockout strain K29.56, an Aldhl ectopic
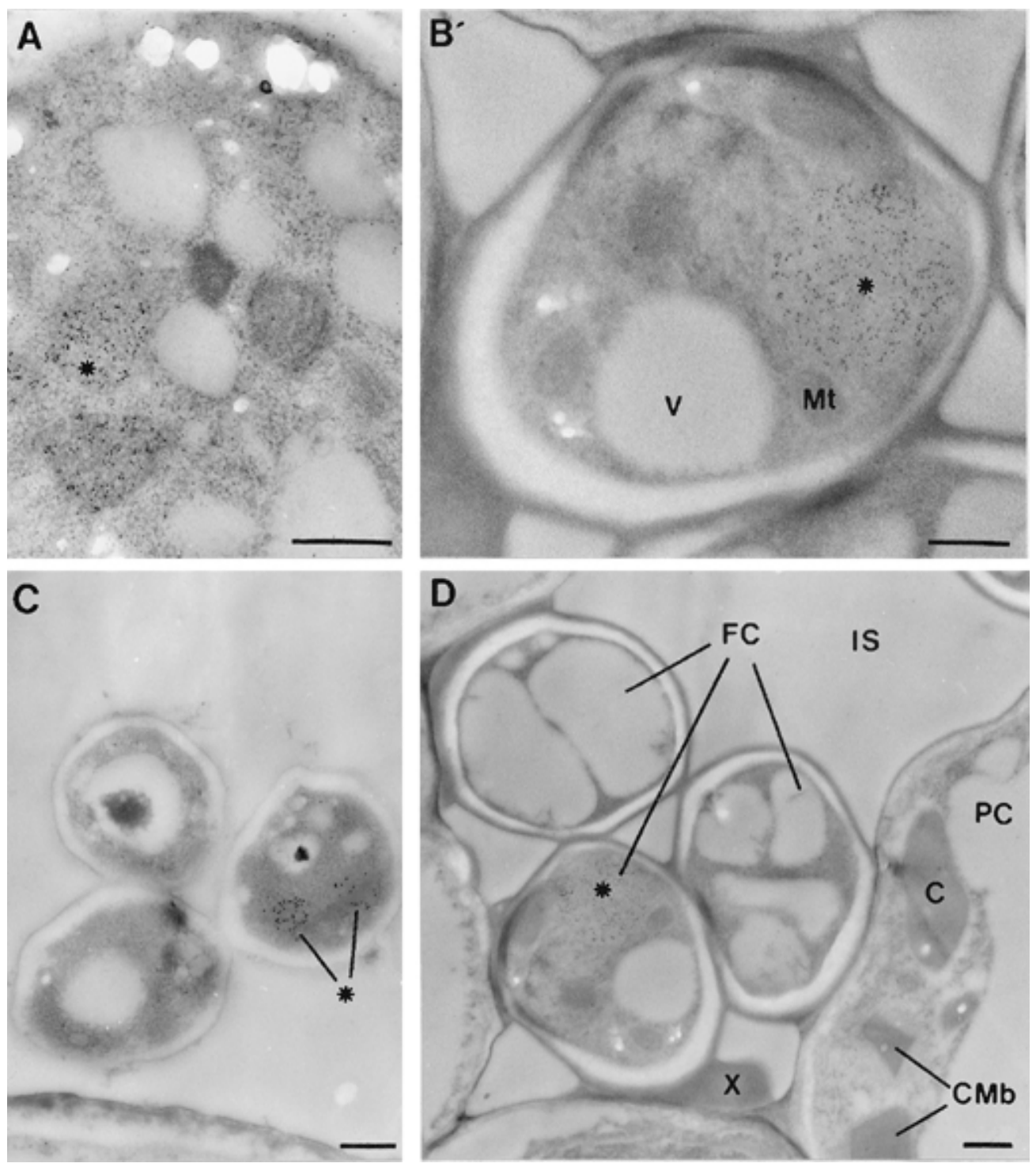

Fig. 4. Ultrathin sections of mycelium or infected plant material. All sections were stained with $10 \mathrm{~nm}$ of gold-conjugated secondary antibodies and antialcohol oxidase primary antibodies. A, Carbon-starved mycelium of Cladosporium fulvum grown in vitro and incubated. B and D, Mycelium in planta at 14 days postinoculation (dpi). C, Mycelium in planta at 2 dpi. $*=$ peroxisome; $\mathrm{C}=$ chloroplast; $\mathrm{CMb}=$ crystal containing microbody; $\mathrm{FC}=$ fungal cell; $\mathrm{IS}=$ intercellular space; $\mathrm{Mt}=$ mitochondrion; $\mathrm{PC}=$ plant cell $\mathrm{V}=$ vacuole; $\mathrm{X}=$ extracellular matrix. $\mathrm{Bars}=1 \mu \mathrm{m}$. 
strain K29.55, and two mutants lacking the Aox 1 gene $(\Delta 12$ and $\Delta 103)$. All mutants showed normal growth and sporulation on solid media, including media with oleate as sole carbon source.

Infections were assessed qualitatively by visual inspection at $6,10,14$, and $18 \mathrm{dpi}$. All infections were normal, including K29.56, except for the Aoxl knockout strains $\Delta 103$ and $\Delta 12$, which produced markedly less sporulation than the controls. The infections were repeated at least once, and the diminution of sporulation was apparent each time (data not shown). Pathogenicity was assessed quantitatively by measuring spore production from a $0.5 \mathrm{~g}$ aliquot of equivalent infected and control leaf samples at 14 and $15 \mathrm{dpi}$ for the $\Delta$ Aoxl and $\Delta$ Aldh1 strains, respectively. Infection with the knockout strains $\Delta 103$ and $\Delta 12$ produced markedly less spores than the wild type. The Aldh1 knockout K29.56 produced as many spores as the wild type (Fig. 10).

The reduced pathogenicity of the Aoxl knockout strains was further investigated by measuring mannitol dehydrogenase $(\mathrm{MtDH})$ activity of infected leaf samples during infection. $\mathrm{MtDH}$ was isolated from $C$. fulvum and used as a measure of fungal biomass because it appears to accumulate in parallel with fungal DNA (Joosten et al. 1990). MtDH activity is absent in uninfected leaves. Crude protein extracts from infected tomato leaves were assayed for $\mathrm{MtDH}$ activity. Figure 11 shows the MtDH activity of leaf material per gram at different time points. The growth of the wild-type strain was more extensive than the transformed strains, as determined by the increase in MtDH activity. The reduction in biomass in the mutants was observed in two separate experiments and was statistically significant.

\section{DISCUSSION}

The deduced amino acid sequence of pSI-47 showed a $65 \%$ identity to AOXs from methylotrophic yeasts, suggesting the presence and expression of an AOX in the filamentous ascomycete $C$. fulvum. FAD containing short-chain AOXs previously were purified only from methylotrophic yeasts and basidiomycetes (Bringer et al. 1979; Janssen et al. 1965; Kerwin and Ruelius 1969; Nishida and Eriksson 1987).
Expression of Aoxl is complex. Transcript and protein accumulation was induced by carbon starvation but repressed by nitrogen starvation. Nitrogen starvation also repressed Aoxl expression in $H$. polymorpha (Egli 1982). The C. fulvum gene appeared to be abundantly expressed in planta, especially between 10 and 12 dpi. Apoplastic fluids from infected plant leaves contain large amounts of glucose and fructose at this stage (Joosten et al. 1990). These results appear to be in conflict because hexose strongly suppressed expression of Aoxl in vitro. The increase in fungal biomass might deplete the sucrose in areas of fungal growth, thus creating localized carbon-starvation conditions that would induce the expression of Aoxl. Alternatively, it is likely that plant-derived signals other than carbon nutrition act to induce expression of Aoxl.

Enzyme activity was detected readily in starved mycelial samples and from infected plants. The substrate specificity of the enzyme was similar to that found for AOX in methylotrophic yeasts and wood rot fungi. The $K_{m}$ value for methanol was estimated to be approximately 20 times higher than the $K_{m}$ value of AOX1 from $H$. polymorpha (Van Dijken et al. 1976b). Compounds in the crude protein extract that were

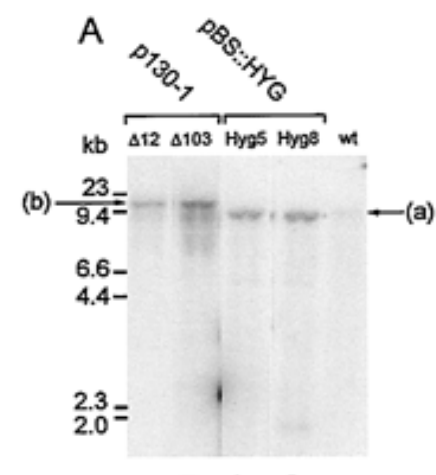

Probe 2

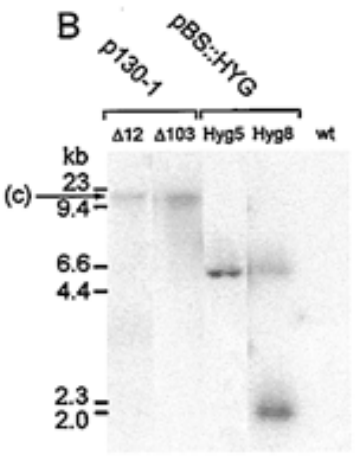

Probe 3
Fig. 6. Southern blot analysis of KpnI-digested genomic DNA of different transformants and wild-type Cladosporium fulvum. A, Probe 2 hybridized with a labeled 600-bp polymerase chain reaction fragment. B, Probe 3 hybridized with a labeled 700-bp BamHI-HindIII fragment from pBluescript SK:: hygromycin.
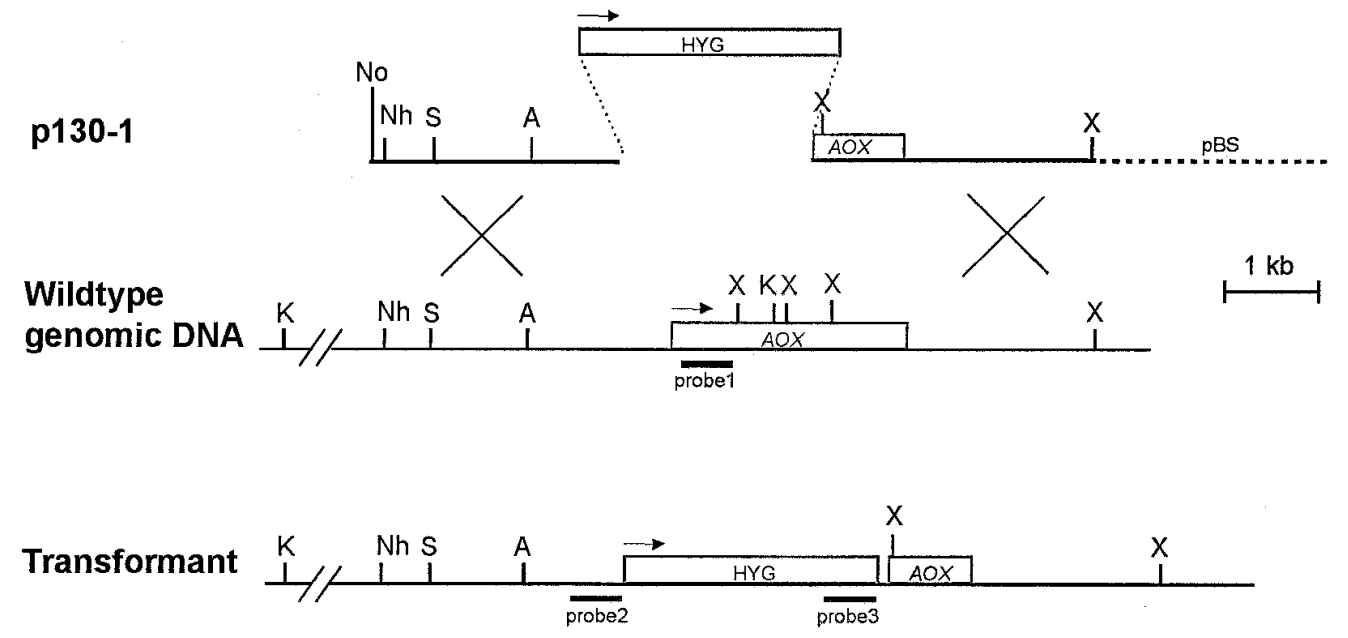

Fig. 5. Map of plasmid p130-1 and replacement of the Aoxl gene (AOX) by the hygromycin cassette (HYG) following transformation. Restriction sites: $\mathrm{A}=$ ApaI $; \mathrm{K}=\operatorname{KpnI} ; \mathrm{Nh}=$ NheI; No = Not $\mathrm{I} ; \mathrm{S}=$ Spe $\mathrm{I} ; \mathrm{X}=$ XhoI. Homology regions of the probes used in different experiments are indicated. 
used for the enzyme assays, however, may have affected the activity of the enzyme. The enzyme was active over a broad pH range, as it is for other AOXs (Nishida and Eriksson 1987; Patel et al. 1981; Van der Klei et al. 1990). The C. fulvum AOX1 was much more temperature sensitive than AOX from $H$. polymorpha, which retained activity after $1 \mathrm{~h}$ at $45^{\circ} \mathrm{C}$ (Van der Klei et al. 1990). This reflects the observation that $H$. polymorpha can be grown at $42^{\circ} \mathrm{C}$ (Barnett et al. 1983).

Polyclonal antibodies raised against AOX1 from $H$. polymorpha cross reacted strongly with AOX from $C$. fulvum. The immunological reaction was highly specific, as shown by Western blot analysis. From the immunolocalization experiments, it can be concluded that AOX is localized in peroxisomes, which is consistent with the presence of a peroxisomal targeting signal at the $\mathrm{C}$ terminus of the protein. The protein could be detected at early and late stages of infection but not at 8 dpi. At $2 \mathrm{dpi}$, the fungus was still growing on the outside of the leaf, presumably where the environment is poor in carbon. This would induce the expression of Aoxl. The amount of fungal biomass at early stages of infection is, however, too low to analyze the expression of genes by Northern blot analysis. At 7 or $8 \mathrm{dpi}$, the failure to detect the protein or transcript may reflect a rich-nutrient environment in the apoplast that becomes depleted as infection proceeds.

The strong expression of Aoxl at early and late stages of infection suggests a role for the enzyme in the pathogenicity process. Gene disruption mutants were obtained at a high frequency, probably as a result of the large size of the flanking DNA used in the disruption vector. All the mutants that lacked the wild-type size band when hybridized with an Aoxlupstream fragment also lacked AOX activity. This indicates that the AOX activity detected in crude protein extract from a wild-type strain was encoded by the single-copy Aoxl.

The pathogenicity of two transformants lacking Aoxl was determined and compared with control strains containing ectopic integrations of the vector strains transformed with the HYG gene and a wild-type strain. The results clearly show that the mutants lacking Aoxl are reduced in growth, as determined by spore fecundity and MtDH activity that becomes evident at later stages of infection. This corresponds to the expression pattern of Aoxl in infected plants where mRNA levels strongly increase from 12 dpi onward. The genereplacement mutants show a strong reduction in sporulation at 14 dpi compared with the wild-type strains. Southern blot

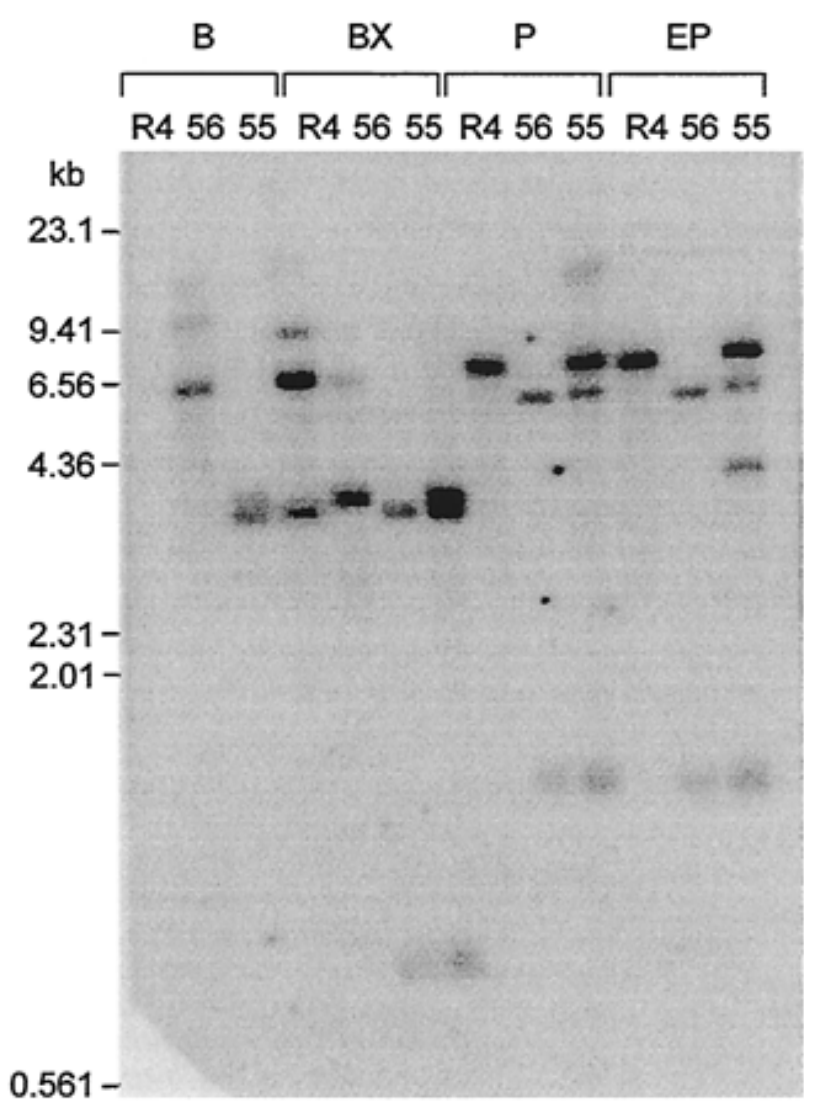

Fig. 8. Southern blot analysis of the wild-type (R4) ectopic insertion strain 55 and replacement strain 56 digested with BamHI (B) and XbaI (X) or PstI (P) and EcoRI (EP) and probed with the Aldhl gene cDNA insert.
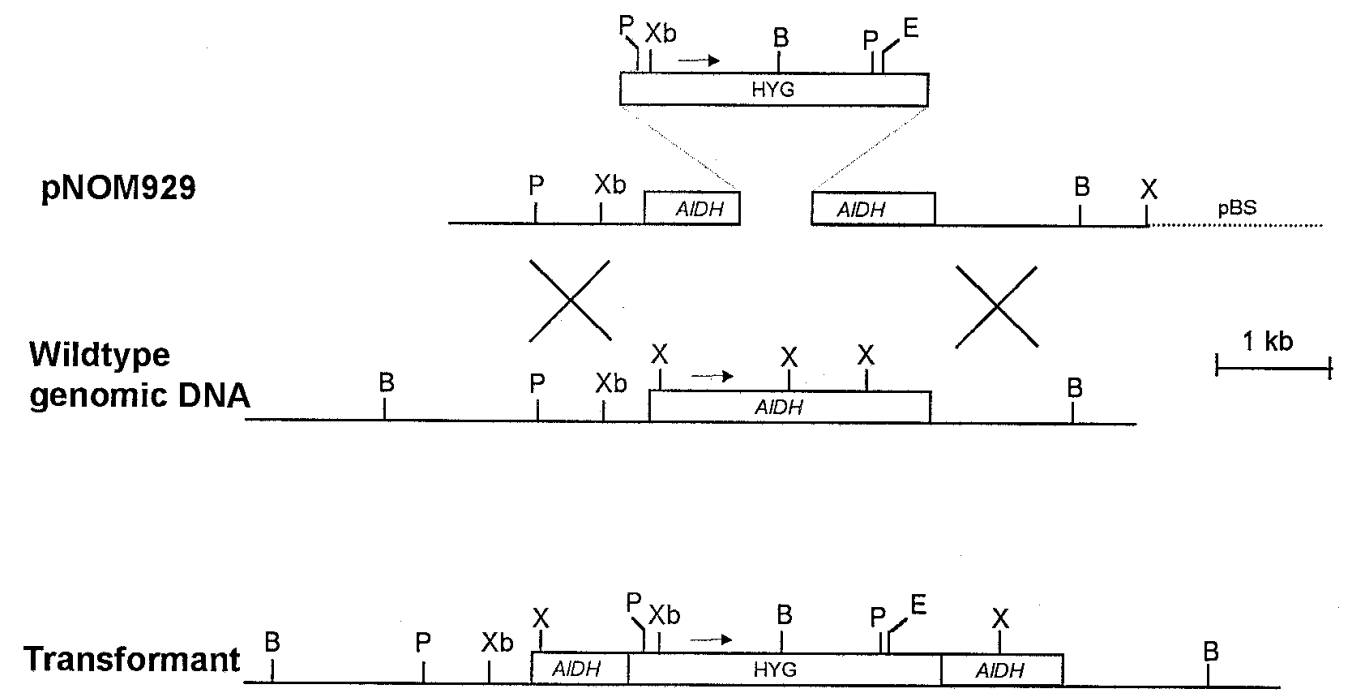

Fig. 7. Map of plasmid pNOM929 and replacement of the Aldh1 gene by the hygromycin cassette (HYG). Restriction sites: $\mathrm{P}=P s t \mathrm{I} ; \mathrm{Xb}=X b a \mathrm{I}$; $\mathrm{B}=$ BamHI; $\mathrm{X}=$ XhoI; E = EcoRI. 
analysis of the gene-replacement mutants showed that, apart from the integration of the HYG gene at the Aoxl site, no DNA fragments had integrated at other sites in the genome. Thus, it is very likely that the reduction in pathogenicity of the Aoxl strains was a result of the disruption of the Aoxl gene.

A knockout mutant of Aldhl also was obtained. The lack of ALDH activity and the sequence of the encoded protein strongly suggests that Aldhl encodes a single-copy acetaldehyde dehydrogenase. The properties of the enzyme appear similar to that of other fungal ALDHs. Significantly, the

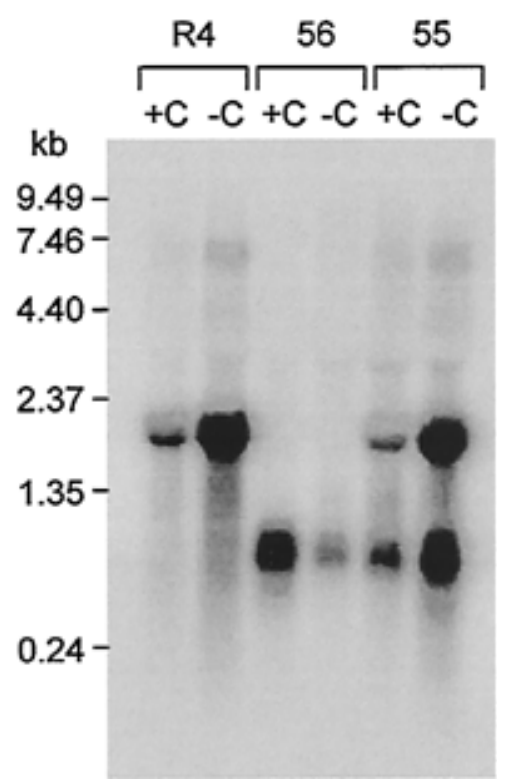

Fig. 9. RNA extracted from race 4 (R4), the ectopic transformants 55, or the replacement 56 under full-carbon $(+C)$ or carbon-limiting $(-C)$ conditions and probed with Aldhl gene cDNA.

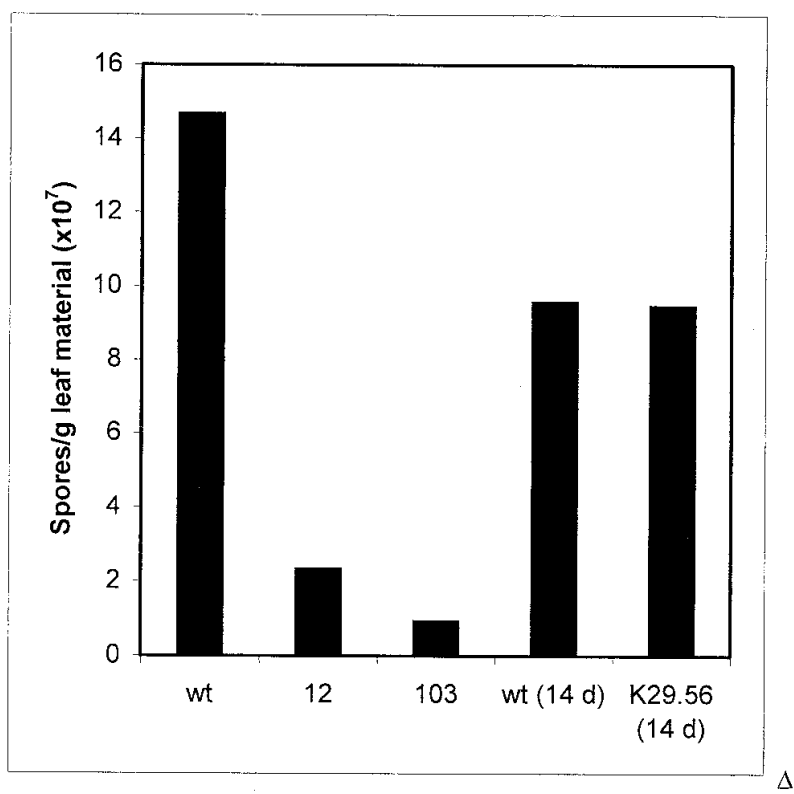

Fig. 10. Quantification of sporulation on tomato leaves after infection with the Race 4 wild type and $\Delta 12, \Delta 103$, and two Aoxl gene replacement strains 15 days postinfection (dpi). Race 4 wild type and K29.56 and the Aldh1 gene replacement strain were analyzed 14 dpi. knockout mutants appeared unaffected in pathogenicity, discounting a key role for ALDH during infection.

The role of AOX1 in pathogenicity is not yet clear. It may be that it contributes to metabolism by conversion of ethanol or methanol, which are both present in tomato leaves (Segers 1998). AOX1 may function to remove ethanol that was produced as a result of fermentation. As AOX1 does not yield NADH (unlike alcohol dehydrogenase), activity might avoid redox imbalance. The produced acetaldehyde could be rereduced to ethanol by alcohol dehydrogenase, another enzyme found in carbon-starved mycelia and infected plants (Coleman et al. 1997), or further oxidized to acetate by ALDH. Alternatively, the function of AOX may be to remove methanol by producing formaldehyde. In this respect it is interesting that Botrytis cinerea expresses a gene with homology to formaldehyde dehydrogenase (EMBL database no. CNS01D9B). Formaldehyde dehydrogenase converts formaldehyde to formate. Formate dehydrogenase, an enzyme whose cognate gene appears in the expressed sequence tag libraries of $B$. cinerea, Magnaporthe grisea (nos. AA415108 and Mg0065), Mycosphaerella graminicola (nos. AW180713.1 and MgA0863f), and C. fulvum (nos. AF4792047 and CFC161-R), would convert formate to carbon dioxide (Van Dijken et al. 1976a). The entire pathway for methanol oxidation appears to be present and expressed in a range of fungal pathogens. A third hypothesis is that the role of AOX1 is to produce $\mathrm{H}_{2} \mathrm{O}_{2}$, perhaps as a cosubstrate for a peroxidase. Distinguishing between these hypotheses will require a combination of genetic and biochemical approaches. Such experiments also will throw light on the hitherto neglected role of the peroxisome in pathogenic metabolism.

\section{MATERIALS AND METHODS}

\section{Fungal isolates and culture conditions.}

C. fulvum race 4 was maintained on V8 agar as described by Harling et al. (1988). Mycelium for DNA and RNA extractions and for protoplasts was grown in liquid B5 medium as described (Coleman et al 1997). The major nitrogen source in $\mathrm{B} 5$ is nitrate.

\section{Fungal transformation.}

Protoplasts were prepared as described by Harling et al. (1988), except cultures were grown for 2 days in B5. Transformation of protoplasts was carried out as described by Oliver et al. (1987), except the mycelium was digested with 15 mg of Glucanez per ml (Novo Nordisk, Bagsvaerd, Denmark). The transformants were single spored and screened for the replacement of Aoxl by the HYG cassette with a colony-lift hybridization method (Arganoza and Akins 1995). Plates with V8 medium containing $100 \mu \mathrm{g}$ of hygromycin B per ml were inoculated with conidia of the transformants. A sterile nylon filter (Hybond N, Amersham, Hørsholm, Denmark) was placed on top of the agar, and the mycelium was allowed to grow for 7 days, after which the hyphae penetrated into the membrane. The membranes were then treated as described (Arganoza and Akins 1995).

\section{Plant infections.}

Plant infections were carried on tomato (Lycopersicon esculentum L.) plants carrying Cf4 at the 3- to 4-leaf stage, es- 
sentially as described by Jones et al. (1993), with a spore suspension of approximately 105 or 108 spores per milliliter to infect paclobutrazol-treated plants.

\section{Spore washes.}

Infected plant material $(0.5 \mathrm{~g})$ taken from three leaflets was transferred to a 15-ml Falcon tube containing $5 \mathrm{ml}$ of $\mathrm{H}_{2} \mathrm{O}$ and $0.01 \%$ Tween-20. The tubes were shaken vigorously for $1 \mathrm{~h}$. A 1-ml sample was taken and transferred to an Eppendorf tube and centrifuged for $30 \mathrm{~min}$ to concentrate the spores. Supernatant was removed $(900 \mu \mathrm{l})$, and the spores in the remaining $100 \mu \mathrm{l}$ were counted with a haemocytometer.

\section{Nucleic acid manipulations.}

DNA manipulations were carried out by standard techniques (Sambrook et al. 1989). Fungal genomic DNA was prepared as described in Raeder and Broda (1985). To screen for Aldh1 gene-replacement events, DNA was amplified with Aldh1 GGTGGATCCAGTCAGCGGCAAGTTCTT and Aldh2 CGCTCACCCCCCTTCCCATC with 30 cycles of $60 \mathrm{~s}$ at $94^{\circ} \mathrm{C}, 60 \mathrm{~s}$ at $65^{\circ} \mathrm{C}$, and $120 \mathrm{~s}$ at $72^{\circ} \mathrm{C}$. These primers amplified a $1.6-\mathrm{kb}$ fragment from genomic DNA and a $2.9-\mathrm{kb}$ fragment from pNOM929. Southern blots were prepared by digesting $3 \mu \mathrm{g}$ of genomic DNA, separating the digested DNA on a $0.8 \%$ agarose-Tris-borate-EDTA gel, and vacuum blotting onto Zetaprobe GT blotting membrane (Biorad, Hercules, CA, U.S.A.) by a vacuum blotting system (VacuGeneXL, Pharmacia, Hørsholm, Denmark). RNA was extracted from fungal and plant tissue with the Hybaid RNA isolation kit (Ashford, U.K.), in accordance with the manufacturer, with $0.01 \% \beta$-mercaptoethanol added to the extraction buffer. mRNA was prepared with the poly(A) Quik mRNA isolation kit from Stratagene (Amsterdam, The Netherlands), according to the manufacturer's instructions.

Northern blots were prepared and probed as described (Coleman et al. 1997). After hybridization, blots were quantified with a PhosphorImager Model 425E from Molecular Dynamics (Sunnyvale, CA, U.S.A.) and ImageQuant version 3.3 software. In order to determine the amount of fungal RNA in infected plants and to correct for different amounts of RNA in different lanes, the quantified hybridization signals were related to the hybridization signal of $C$. fulvum actin, a constitutively expressed gene (Van den Ackerveken et al. 1993). The probe was released from pGEM actin with EcoR1 and Sal1.

Two genomic libraries were screened to isolate genomic clones containing the Aoxl gene. From a genomic library prepared in the pBK-CMV phagemid vector (Stratagene), a genomic clone with a $5.5-\mathrm{kb}$ insert was isolated and named $82-\mathrm{I}$. Clone 47II- 2 containing an insert of $11 \mathrm{~kb}$ was isolated from a library prepared in $\lambda$ Bluestar (Novagen, Madison, WI, U.S.A.). The libraries were screened according to the manufacturer's instructions. DNA was sequenced with the Thermo Sequenase dye terminator cycle sequencing kit (Amersham) and an ABI 377 automated sequencer.

\section{Construction of the gene-replacement vectors.}

Plasmid pBS::HYG (B. Henricot and R Oliver, unpublished) contains a 2.7-kb SacI-HindIII fragment of the HYG cassette from pAN7-1 (Punt et al. 1987), which confers hygromycin B resistance cloned into the SmaI site in pBS and was used for construction of the gene-replacement vectors. To generate the Aox 1 disruption vector, PCR was carried out with Klentaq polymerase (Clontech, Heidelberg, Germany) and primer pairs AOX-upstream-reverse (5'-ATG CTA GCG TGG TAC AAC ACG CTA TAT C-3') with AOX-upstream-forward (5'-TAG CTA GCA ATC GAG CCA GGG G-3') and AOX3'R (5'-ATA TAA GCT TCA TGA GTC CAG CTC GTC G-3') with AOX3'-F (5'-ATA TAA GCT TTA GTC GCG TTT GCT GAG-3'). The DNA was amplified from genomic lambda clones by 25 cycles of $30 \mathrm{~s}$ at $94^{\circ} \mathrm{C}, 30 \mathrm{~s}$ at $58^{\circ} \mathrm{C}$, and $3 \mathrm{~min}$ at $72^{\circ} \mathrm{C}$. The transformation vector was linearized by digesting with NotI. The digestion mixture was directly used for transformation.

\section{Protein extraction and enzyme assays.}

Crude protein extracts were prepared by grinding the tissue in liquid nitrogen and transferring the powder to a tube containing phosphate buffer $\left(50 \mathrm{mM} \mathrm{K} \mathrm{HPO}_{4}, \mathrm{pH}\right.$ 7.5) with $500 \mu \mathrm{M}$ phenylmethylsulfonyl fluoride (PMSF). The homogenate was thoroughly mixed, centrifuged for $10 \mathrm{~min}$ at $14,000 \mathrm{~g}$ and $4^{\circ} \mathrm{C}$, and the supernatant was transferred to a new tube. AOX assays were carried out as described by Van der Klei et al. (1990). Substrates were added to a final concentration of $100 \mathrm{mM}$, unless indicated otherwise.

The $\mathrm{pH}$ optimum of the AOX1 enzyme was studied by measuring the activity of crude protein extract in buffers with different $\mathrm{pH}$. For the $\mathrm{pH}$ range 5.5 to 8.0 , a $50 \mathrm{mM} \mathrm{K}{ }_{2} \mathrm{HPO}_{4}$ buffer was used. Tris- $\mathrm{HCl}$ buffer at $50 \mathrm{mM}$ was used for $\mathrm{pH}$ 7.5 to 9.0 and Glycine- $\mathrm{NaOH}$ buffer at $50 \mathrm{mM}$ for $\mathrm{pH} 8.5$ to 10.5. The temperature sensitivity of AOX1 was determined by incubation of the crude extract at different temperatures for 15 min, after which the activity was directly measured at $30^{\circ} \mathrm{C}$ in $50 \mathrm{mM} \mathrm{K}_{2} \mathrm{HPO}_{4}$ buffer, $\mathrm{pH} 7.5$.

Mannitol dehydrogenase activity in infected plant material was assayed as follows. Three leaflets from each of two leaves were ground in liquid $\mathrm{N}_{2}$ and the powder transferred

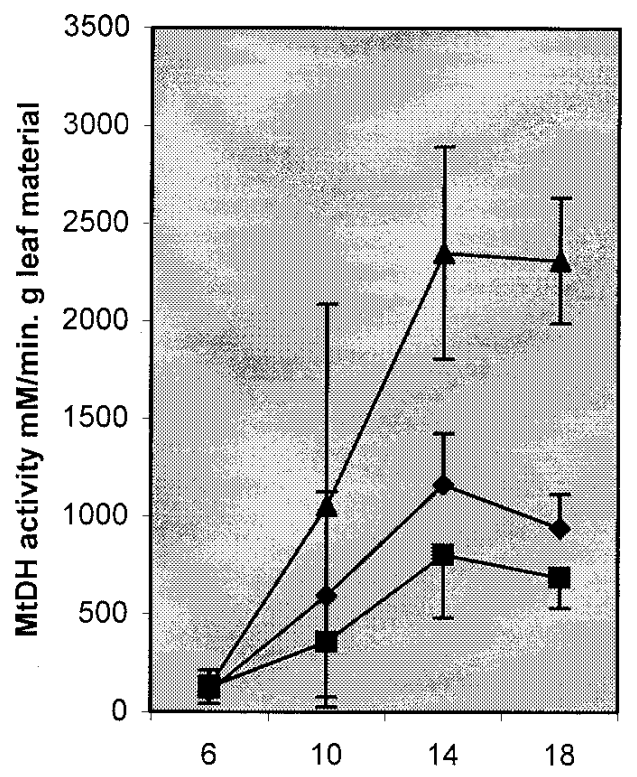

Fig. 11. Mannitol dehydrogenase activity in protein extracts from tomato leaves infected with knockout mutants $\Delta 12$ (diamond), $\Delta 103$ (square), and wild-type (triangle) Cladosporium fulvum. Leaves were harvested at $6,10,14$, and 18 days postinfection. 
to an Eppendorf containing $1 \mathrm{ml}$ of $50 \mathrm{mM}$ Tris- $\mathrm{HCl}(\mathrm{pH}$ 7.5) with $500 \mu \mathrm{M}$ PMSF. MtDH activity was assayed by monitoring oxidation of NADPH $\left(\varepsilon_{340}=6,220\right)$ at $340 \mathrm{~nm}$ with fructose as substrate (Morton et al. 1985). The reaction mixture consisted of $0.25 \mathrm{mM}$ NADPH, $0.8 \mathrm{M}$ fructose, and $25 \mu \mathrm{l}$ of crude protein extract in $50 \mathrm{mM}$ Tris- $\mathrm{HCl}(\mathrm{pH} 7.5)$ in a total volume of $1 \mathrm{ml}$. Fructose was added to start the reaction.

\section{Sodium dodecyl sulfate (SDS)-polyacrylamide gel electrophoresis (PAGE), Western blotting, and immunological detection of proteins.}

Proteins were separated on $10 \%$ SDS-PAGE gels in a discontinuous system. The proteins were transferred onto Immobilon-P polyvinylidene difluoride membrane (Millipore, Glostrup, Denmark) with a semidry blotting apparatus. Gel electrophoresis and blotting were carried out essentially as described in Sambrook et al. (1989).

Immunological detection was carried out with alkaline phosphatase-conjugated goat-anti-rabbit antibodies (DAKO, Glostrup, Denmark) in the dilution recommended by the manufacturer, as described in Sambrook et al. (1989).

\section{Immunocytochemical localization.}

Plant leaves were cut into small, 1- to 2-mm strips, and fungal mycelia were blotted dry slightly before incubation with fixative $\left(75 \mathrm{mM} \mathrm{K} \mathrm{HPO}_{4} ; 3 \%\right.$ [vol/vol] glutaraldehyde, $\mathrm{pH}$ 8.0). Fixation was carried out for $2 \mathrm{~h}$ at room temperature, or overnight at $4^{\circ} \mathrm{C}$. Plant tissue was infiltrated with a vacuum chamber. The fixed tissue was subsequently dehydrated in 30 , 50,75 , and $100 \%$ ethanol for 5 min each. Then it was incubated in $100 \%$ ethanol for $30 \mathrm{~min}$ to $1 \mathrm{~h}$, then in a mixture of $50 \%$ ethanol-50\% London Resin White (LR White, SPI Supplies, West Chester, PA, U.S.A.), and finally overnight at $4{ }^{\circ} \mathrm{C}$ in $100 \%$ LR White. The tissue was incubated with fresh $100 \%$ LR White for 1 to $2 \mathrm{~h}$, transferred to PCR tubes filled with LR White, and polymerized at $60^{\circ} \mathrm{C}$ overnight.

Ultrathin sections were prepared with a Reichert OM-U3 ultramicrotome with a diamond knife. The sections were transferred to formvar-coated copper grids for direct viewing and to formvar-coated nickel grids for immunolocalization experiments. Sections were stained with an LKB Ultrostainer-Carlsberg system 2168 with 5\% aqueous uranyl acetate, $20 \mathrm{~min}$ at $40^{\circ} \mathrm{C}$, and Reynolds' lead citrate for 1.5 min at $20^{\circ} \mathrm{C}$ (Reynolds 1963). Sections were viewed on a CEM 902 transmission electron microscope (Carl Zeiss Inc., Thornwood, NY, U.S.A.). Nickel grids with sections were incubated upside down on top of a 10- $\mu$ l droplet of solution. The sections were blocked with phosphate-buffered saline (PBS; $137 \mathrm{mM} \mathrm{NaCl}, 2.7 \mathrm{mM} \mathrm{KCl}, 4.3 \mathrm{mM} \mathrm{Na} \mathrm{HPO}_{4}, 1.4$ $\mathrm{mM} \mathrm{KH} \mathrm{KO}_{4}$ ) containing $1 \%$ (wt/vol) bovine serum albumin (BSA) for $2 \mathrm{~h}$ at room temperature and incubated with primary antibody (supplied by M. Veenhuis, Groningen) diluted in PBS-BSA overnight at $4{ }^{\circ} \mathrm{C}$. The grids were washed five times for 5 min with PBS-BSA and incubated with a 1:30 dilution of goat anti-rabbit 10-nm gold-labeled antibodies (British Biocell International, Cardiff, U.K.) in PBSBSA for $1 \mathrm{~h}$ at room temperature. The grids were washed three times for $5 \mathrm{~min}$ with PBS-BSA and three times for 5 min with distilled water. The sections were subsequently stained with uranyl acetate and lead citrate.

\section{LITERATURE CITED}

Arganoza, M. T., and Akins, R. A. 1995. A modified colony-filterhybridization protocol for filamentous fungi. Trends Genet. 11:381382.

Barnett, J. A., Payne, R. W., and Yarrow, D. 1983. YEASTSCharacteristics and Identification. Cambridge University Press, U.K.

Bringer, S., Sprey, B., and Sahm, H. 1979. Purification and properties of alcohol oxidase from Poria contigua. Eur. J. Biochem. 101:563-570.

Cavener D. R. 1992. GMC oxidoreductases: A newly defined family of homologous proteins with diverse catalytic activities. J. Mol. Biol. 223:811-814.

Coleman, M., Henricot, B., Arnau, J., and Oliver, R. P. 1997. Starvationinduced genes of the tomato pathogen Cladosporium fulvum are also induced during growth in planta. Mol. Plant-Microbe Interact. 10:1106-1109.

De Hoop, M. J., and Ab, G. 1992. Import of proteins into peroxisomes and other microbodies. Biochem. J. 286:657-669.

De Wit, P. J., and Joosten, M. H. 1999. Avirulence and resistance genes in the Cladosporium fulvum-tomato interaction. Curr. Opin. Microbiol. 2:368-373.

Egli, T. 1982. Regulation of protein synthesis in methylotrophic yeasts: Repression of methanol dissimilating enzymes by nitrogen limitation. Arch. Microbiol. 131:95-101.

Gould, S. J., Keller, G. A., Hosken, N., Wilkinson, J., and Subramani, S 1989. A conserved tripeptide sorts proteins to peroxisomes. J. Cell Biol. 108:1657-1664.

Gurr, S., Unkles, S., and Kinghorn, J. 1987. The structure and organisation of nuclear genes of filamentous fungi. Pages 117-127 in: Gene Structure in Eukaryotic Microbes. J. R. Kinghorn, ed. IRL Press, Oxford, U.K.

Harling, R., Kenyon, L., Lewis, B., Oliver, R., Turner, J., and Coddington, A. 1988. Conditions for efficient isolation and regeneration of protoplasts from Fulvia fulva. J. Phytopathol. 122:143-146.

Hazeu, W., De Bruyn, J. C., and Bos, P. 1972. Methanol assimilation by yeasts. Arch. Microbiol. 87:185-188.

Janssen, F. W., Kerwin, R. M., and Ruelius, H. W. 1965. Alcohol oxidase, a novel enzyme from a basidiomycete. Biochem. Biophys. Res. Commun. 20:630-634.

Jones, D. A., Dickinson, M. J., Balint-Kurti, P. J., Dixon, M. S., and Jones, J. D. G. 1993. Two complex resistance loci revealed in tomato by classical and RFLP mapping of the $C f-2, C f-4, C f-5$, and $C f-9$ genes for resistance to Cladosporium fulvum. Mol. Plant-Microbe Interact. 6:348-357.

Joosten, M. H. A. J., Hendrickx, L. J. M., and De Wit, P. J. G. M. 1990. Carbohydrate composition of apoplastic fluids isolated from tomato leaves inoculated with virulent or avirulent races of Cladosporium fulvum syn. Fulvia fulva. Neth. J. Plant Pathol. 96:103-112.

Karpovich-Tate, N., Spanu, P., and Dewey, F. M. 1998. Use of monoclonal antibodies to determine biomass of Cladosporium fulvum in infected tomato leaves. Mol. Plant-Microbe Interact. 11:710-716.

Kato, N., Tani, Y., and Ogata, K. 1974. Enzyme system for methanol oxidation in yeasts. Agric. Biol. Chem. 38:675-677.

Kerwin, R. M., and Ruelius, H. W. 1969. Production of alcohol oxidase by several basidiomycetes. Appl. Microbiol. 17:347-351.

Morton, N., Dickerson, A., and Hammond, J. 1985. Mannitol metabolism in Agaricus bisporus: Purification and properties of mannitol dehydrogenase. J. Gen. Microbiol. 131:2885-2890.

Nishida, A., and Eriksson, K. 1987. Formation, purification, and partial characterization of methanol oxidase, $\mathrm{a} \mathrm{H}_{2} \mathrm{O}_{2}$ producing enzyme in Phanerochaete chrysosporium. Biotechnol. Appl. Biochem. 9:325338.

Oliver, R. P., Henricot, B., and Segers, G. 2000. Cladosporium fulvum, cause of leaf mould of tomato. Pages 65-91 in: Fungal Pathology. J. Kronstad, ed. Kluwer Academic Publishers, Dordrecht, The Netherlands.

Oliver, R., Roberts, I., Harling, R., Kenyon, L.,. Punt, P., Dingemanse, M., and Van den Hondel, C. 1987. Transformation of Fulvia fulva, a fungal pathogen of tomato to hygromycin B resistance. Curr. Genet. 12:231-233.

Patel, R. N., Hou, C. T., Laskin, A. I., and Derelanko, P. 1981. Microbial oxidation of methanol: Properties of crystallized alcohol oxidase from a yeast, Pichia sp. Arch. Biochem. Biophys. 210:481-488.

Punt, P. J., Oliver, R. P.,. Dingemanse, M. A , Pouwels, P. H., and Van den Hondel, C. A. M. J. J. 1987. Transformation of Aspergillus 
based on the hygromycin B resistance marker from Escherichia coli. Gene 56:117-124.

Raeder, U., and Broda, P. 1985. Rapid preparation of DNA from filamentous fungi. Lett. Appl. Microbiol. 1:17-20.

Reynolds, E. G. 1963. The use of lead citrate at high pH as an electronopaque stain in electron microscopy. J. Cell Biol. 17:208-212.

Rost, B., Sander, C., and Schneider, R. 1994. PHD—An automatic mail server for protein secondary structure prediction. CABIOS 10:53-60.

Sahm, H., and Wagner, F. 1973. Microbial assimilation of methanol. The ethanol and methanol-oxidizing enzymes of the yeast Candida boidinii. Eur. J. Biochem. 36:250-256.

Sambrook, J., Fitsch, E., and Maniatis, T. 1989. Molecular Cloning: A Laboratory Manual. Cold Spring Harbor Laboratory Press, Cold Spring Harbor, NY, U.S.A.

Segers, G. 1998. Isolation and characterisation of fungal genes, expressed during the infection of tomato by Cladosporium fulvum. Ph.D. thesis. University of East Anglia, Norwich, U.K.

Van den Ackerveken, G. F. J. M., Van Kan, J. A. L., Joosten, M. H. A. J., Muisers, J. M., Verbakel, H. M. and De Wit, P. J. G. M. 1993. Characterisation of two putative pathogenicity genes of the fungal tomato pathogen Cladosporium fulvum. Mol. Plant Microbe Interact. 6:210-
215.

Van der Klei, I. J., Bystrykh, L. V., and Harder, W. 1990. Alcohol oxidase from Hansenula polymorpha CBS 4732. Pages 420-427 in: Methods in Enzymology, Vol. 188. M. E. Lidstrom, ed. Academic Press, Orlando, FL, U.S.A.

Van Dijken, J. P., Veenhuis, M., Vermeulen, C. A., and Harder, W. 1975. Cytochemical localization of catalase activity in methanol-grown Hansenula polymorpha. Arch. Microbiol. 105:261-267.

Van Dijken, J. P., Oostra-Demkes, G. J., Otto, R., and Harder, W. 1976a. S-formylglutathione: The substrate for formate dehydrogenase in methanol-utilizing yeasts. Arch. Microbiol. 111:77-83.

Van Dijken J. P., Otto, R., and Harder, W. 1976b. Growth of Hansenula polymorpha in a methanol-limited chemostat. Arch. Microbiol. 111:137-144.

Veenhuis, M., Van Dijken, J. P., and Harder, W. 1976. Cytochemical studies on the localization of methanol oxidase and other oxidases in peroxisomes of methanol-grown Hansenula polymorpha. Arch. Microbiol. 111:123-135.

Wierenga, R. K., Terpstra, P., and Hol, W. G. J. 1986. Predictions and occurrence of the ADP-binding beta-alpha-beta fold in proteins, using an amino acid sequence fingerprint. J. Mol. Biol. 187:101-107. 